\title{
Macroplastic Storage and Remobilization in Rivers
}

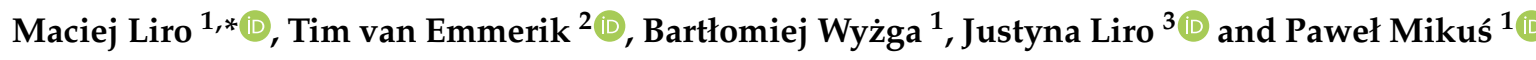 \\ 1 Institute of Nature Conservation, Polish Academy of Sciences, al. Mickiewicza 33, 31-120 Kraków, Poland; \\ wyzga@iop.krakow.pl (B.W.); mikus@iop.krakow.pl (P.M.) \\ 2 Hydrology and Quantitative Water Management Group, Wageningen University, Droevendaalsesteeg 3, \\ 6708 PB Wageningen, The Netherlands; tim.vanemmerik@wur.nl \\ 3 Institute of Geography and Spatial Management, Jagiellonian University, ul. Gronostajowa 7, \\ 30-387 Kraków, Poland; justyna.liro@uj.edu.pl \\ * Correspondence: liro@iop.krakow.pl; Tel.: +48-12-370-35-24
}

Received: 22 June 2020; Accepted: 17 July 2020; Published: 20 July 2020

check for updates

\begin{abstract}
The paper presents a conceptual model of the route of macroplastic debris ( $>5 \mathrm{~mm}$ ) through a fluvial system, which can support future works on the overlooked processes of macroplastic storage and remobilization in rivers. We divided the macroplastic route into (1) input, (2) transport, (3) storage, (4) remobilization and (5) output phases. Phase 1 is mainly controlled by humans, phases $2-4$ by fluvial processes, and phase 5 by both types of controls. We hypothesize that the natural characteristics of fluvial systems and their modification by dam reservoirs and flood embankments construction are key controls on macroplastic storage and remobilization in rivers. The zone of macroplastic storage can be defined as a river floodplain inundated since the beginning of widespread disposal of plastic waste to the environment in the 1960s and the remobilization zone as a part of the storage zone influenced by floodwaters and bank erosion. The amount of macroplastic in both zones can be estimated using data on the abundance of surface- and subsurface-stored macroplastic and the lateral and vertical extent of the zones. Our model creates the framework for estimation of how much plastic has accumulated in rivers and will be present in future riverscapes.
\end{abstract}

Keywords: macroplastic; macroplastic storage; macroplastic remobilization; plastic debris; Anthropocene; human impact; riverine plastic

\section{Introduction}

Plastic debris has been disposed of in the natural environment since the 1960s [1]. Since that time, rivers worldwide have transported this new, synthetic component [1-4], which caused numerous aesthetic, ethical, economic, and environmental problems (for reviews see [3,5-15]. Knowledge of riverine plastic pollution is mainly limited to the microplastic fraction (plastic particles $<5 \mathrm{~mm}$ in size) [16], whereas few studies focused on larger, macroplastic debris (plastic particles $>5 \mathrm{~mm}$ in size) [13]. These studies mostly considered rivers as a transport pathway of land-derived plastic to the ocean. Recent works suggest, however, that rivers may also function as (temporary) sinks for land-based plastic pollution [12,13,15-20], and a potential source of its future remobilization [12,21]. It is important to emphasize that these problems will probably increase in the future, because annual plastic production is predicted to increase six-fold between 2015 and 2050 [4].

Previous works suggested that both natural (e.g., hydrological processes, channel morphology, and riparian vegetation) and anthropogenic characteristics of river catchments (e.g., plastic waste management) control the input and transport of plastic debris in fluvial systems [12,13,15,22-29], and that macroplastic constitutes most of riverine plastic debris in terms of mass [26]. Recent studies show that macroplastic debris may be stored on the surface of alluvium and in riparian vegetation (surface storage) and in river sediments (subsurface storage) [21,30]. Moreover, stored macroplastic 
debris may be remobilized by floodwaters and bank erosion [21,22] and its fragmentation constitutes the main source of secondary microplastic in rivers [12,22]. Taking into account the long preservation of macroplastic debris in the natural environment [1,12], the storage-remobilization cycles of macroplastic debris in fluvial systems may last for decades or centuries (e.g., [19,21]). This implies that the presence of riverine macroplastic and related environmental risk may continue in the future, even when the input of new plastic debris to the fluvial systems is decreased. Macroplastic storage and remobilization processes are overlooked in the literature, but their understanding is fundamental for: (i) the assessment of the amount of plastic accumulated in river systems, (ii) effective targeting of cleanup actions [15], (iii) management of present and future remobilization of plastic, (iv) assessment of related risks, and (v) the influence of macroplastic debris on the aesthetic value of river landscapes [31-33].

From this perspective, precise information is still required on the spatial and temporal extent of the storage of macroplastic debris in river deposits (both surface and subsurface) and riparian vegetation, and the estimation of the potential for macroplastic remobilization caused by water inundation and erosion processes. Recent works showed that macroplastic debris can be detected through visual analysis of present and past sediments [1,21,34], and monitored and mapped with remote sensing methods (e.g., aerial photographs, UAV surveys) [35-41], thus creating a promising methodological perspective for future research. However, a conceptual framework and a theoretical background for research on macroplastic storage and remobilization in fluvial systems are not available.

We therefore developed a framework to support future studies on macroplastic storage and remobilization in river systems. In this paper, we present and discuss a conceptual model of macroplastic route through a fluvial system, describing processes of macroplastic input, transport, storage, remobilization and output. We use this model to identify the main controlling factors for each phase and summarize existing methodological approaches which may be used for the quantification of the controlling factors in future studies. Our goal is to support the systematic development of future hypotheses on the processes of macroplastic storage and remobilization in rivers.

\section{Plastic as a New, Artificial Type of River Load}

The existing paradigm in hydrological and geomorphological sciences divides sediments transported by rivers (so called river load) into mineral and organic types. However, a growing body of evidence suggests that plastic debris may be treated as a new kind of sediment particles and thus a new type of river sediment load because of its ubiquity, longevity, and abundance in the environment [19]. The processes of transport, deposition and remobilization of mineral and organic sediments are controlled by their physical properties (e.g., density, size) and their relation to river size and hydrodynamics [42-45]. Recent insights into interactions of macroplastic debris with fluvial processes documented by laboratory experiments [46,47] and the monitoring of floating $[24,26,27]$ and deposited macroplastic debris [48] suggest that transport, storage and remobilization of macroplastic debris are also partly related to fluvial processes. The main similarities between macroplastic and larger particles of organic debris (e.g., seeds, vegetation propagules, large wood pieces) encompass their relatively low density and large surface area determining their transport by water in flotation (see [45]). Previous works also indicated a dependence of macroplastic transport on river hydrodynamics [27] and types of aquatic vegetation [26,30]. For example, van Emmerik et al. [26] detected a seasonal trend of changes in macroplastic transport related to the seasonal cycle of water hyacinths growth in the Saigon river, Vietnam. However, in the Seine (France) plastic transport was found to increase ten-fold during high discharge in comparison to low discharge [27]. Bruge et al. [48] found that more artificial debris was deposited on riverbanks in a river section characterized by stagnant water, low channel slope and large-size riparian vegetation, highlighting the importance of flow hydrodynamics and river morphology as potential controls on macroplastic storage. Recently, Cozzolino et al. [30] found that macroplastic abundance on the surface of vegetated areas of a tidal zone was higher in comparison to the adjacent unvegetated areas. This suggests that a similar pattern may develop also along densely vegetated riverbanks and delta-backwater zones of dam reservoirs. 
A difference arises when processes of the input of plastic to a river are compared with those for organic debris (cf. [44,49]). The former seem to depend on both anthropogenic (e.g., urbanization, population density, waste management, road density) [29] and natural factors (e.g., wind, surface runoff), while the latter mainly on natural processes (bank erosion, windstorm, landslides) (cf. [44,49]). However, once macroplastic starts to be transported and stored in a fluvial system, natural (e.g., climate, catchment topography, valley and channel morphology) and anthropogenic (dams, embankments) characteristics of the fluvial system seem to influence the transport and storage of macroplastic in a similar way as documented for woody debris [45].

We used the above highlighted similarities and information from the literature to infer the main controls on macroplastic storage and remobilization in rivers.

\section{Conceptual Model of Macroplastic Routing through a Fluvial System}

We divide the route of macroplastic debris through a fluvial system (or its given part, e.g., subcatchment or river reach) into five phases: (1) input, (2) transport, (3) storage, (4) remobilization and (5) output (Figure 1). Then, we assign natural or anthropogenic controls to particular phases of the macroplastic route (Figure 2). Using this systematization, we demonstrate changes in main controls between different phases of the macroplastic route: phase 1 (input of macroplastic) is mainly controlled by anthropogenic factors, phases $2-4$ by natural ones, and phase 5 (output) by both types of factors (Figures 1 and 2). Table 1 summarizes methods for measuring of macroplastic abundance in sediments, which may be applied for the further quantification of phases 3 and 4 .

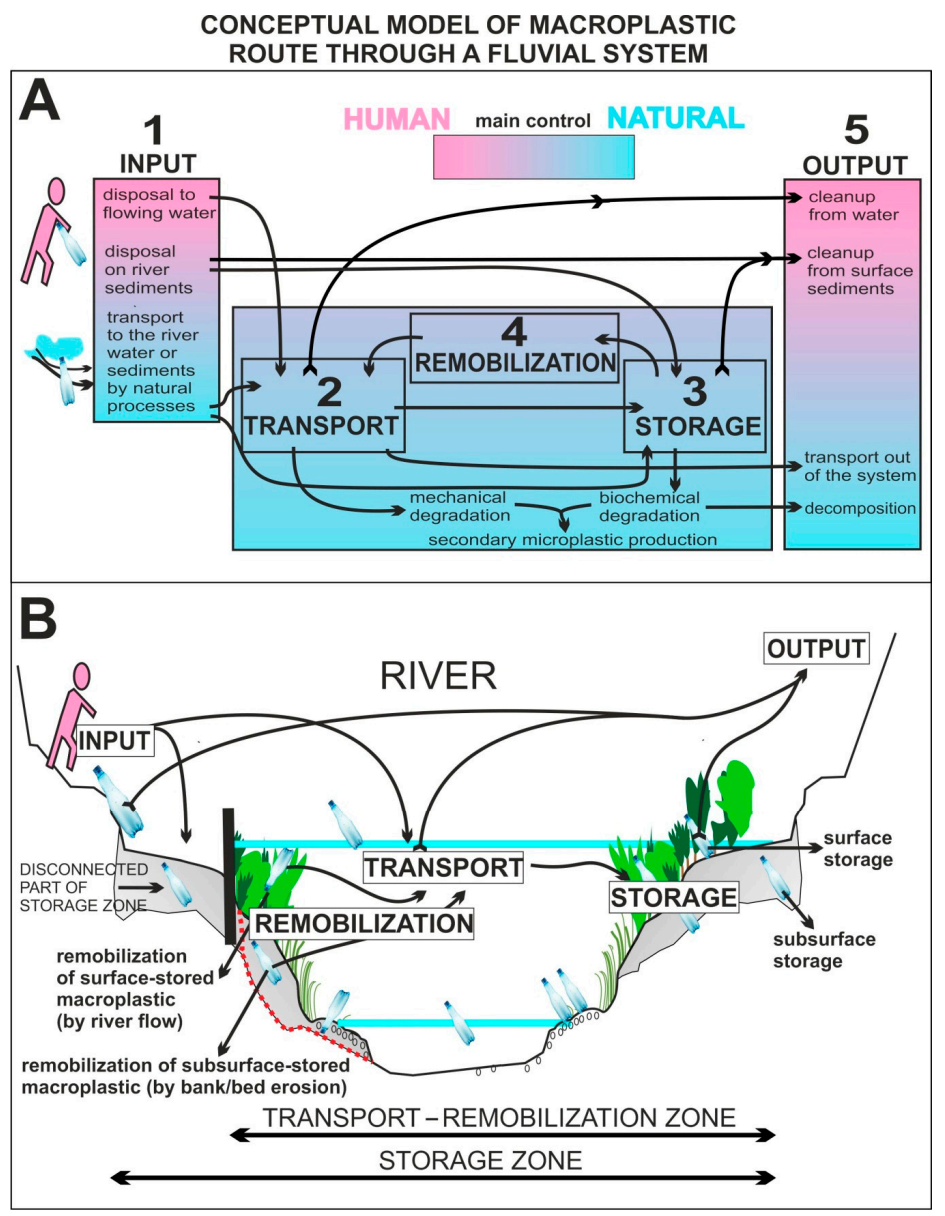

Figure 1. Conceptual model of the route of macroplastic debris through a fluvial system, with indicated sequence of phases $(\mathbf{A})$ and their spatial extent in the cross-section of a river valley (B). 


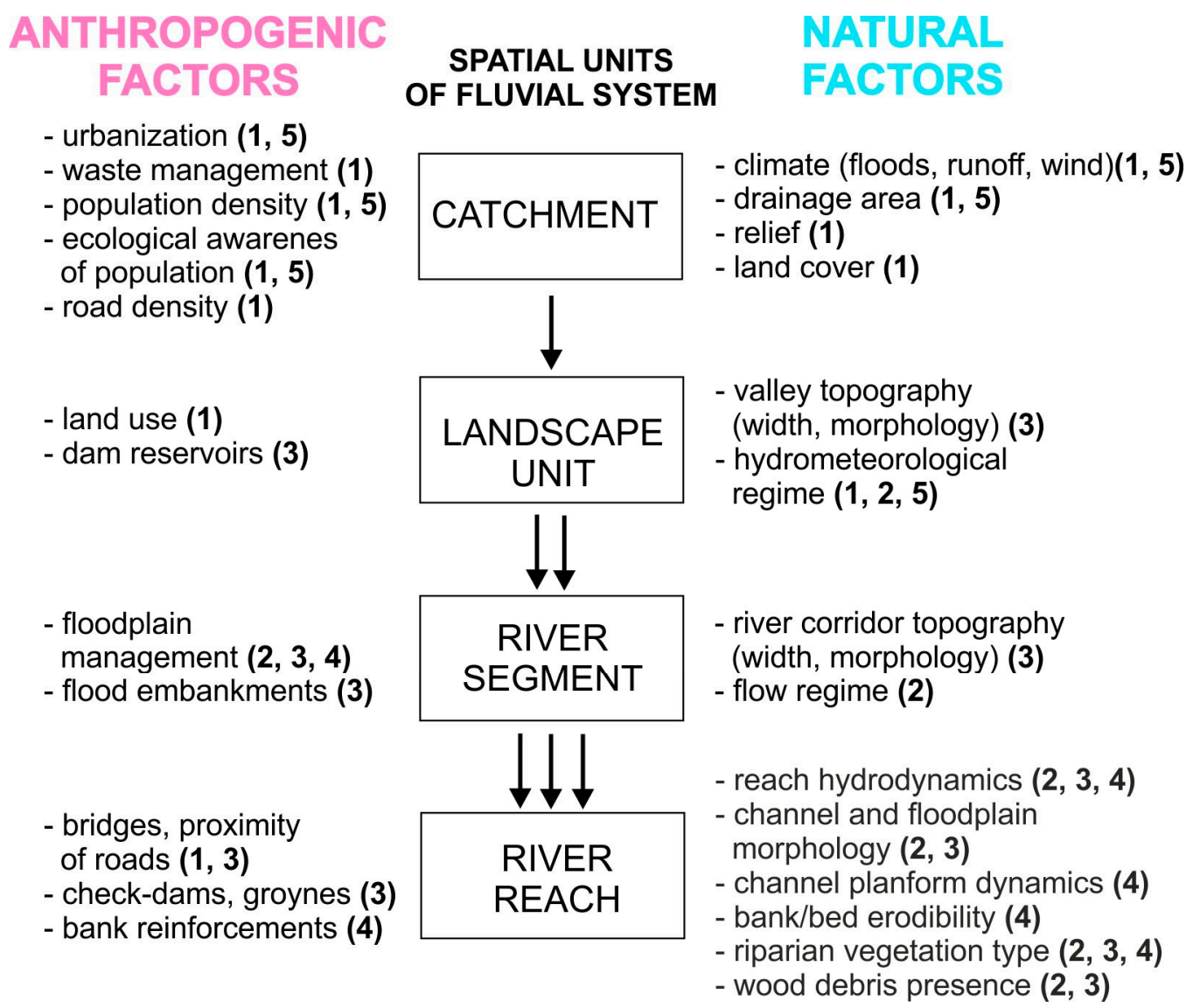

Figure 2. A scheme of anthropogenic and natural factors controlling particular phases of the macroplastic route in different spatial units of a fluvial system. 1-input; 2-transport; 3-storage; 4-remobilization; 5 -output. Arrows indicate the increasing number of controls on the fate of macroplastic debris from larger to smaller spatial units of a fluvial system.

\subsection{Input of Macroplastic to Fluvial System}

The input of macroplastic is defined as the artificial or natural placing of plastic items within the zone of active fluvial processes (channel, floodplain, eroded terraces), facilitating their immediate (input to flowing water) or delayed (e.g., input to floodplain zone and subsequent transport by floodwater) transport by river (phase 2) (Figure 1). Input of plastic debris to fluvial systems is primarily controlled by humans who may dispose litter, including plastic, either scattered in a channel, on riverbanks or floodplain, or concentrated in dumping sites and landfills located in the riparian zone of a river. At the catchment scale, urbanization, population density and waste management are the most important controls on macroplastic input to rivers (e.g., [29,50,51]). At the river reach scale, the location of dumping sites on river floodplains is an important control on a local input of plastic debris (e.g., [52]). Natural processes such as wind or mass movement processes (e.g., landslide) may also act in a similar way [12], but their importance as input factors seems to be lower than that of humans, especially in populated areas and where dense riparian vegetation occurs along a river course (because such vegetation can trap macroplastic outside the part of a river valley affected by fluvial processes). At the catchment scale, the input of plastic can be indirectly assessed based on the natural and anthropogenic characteristics of the area (e.g., [29]). At smaller spatial scales, the location and extent of input zones can be directly mapped during field surveys (e.g., [52]) and from remote sensing material such as aerial photographs taken during low-altitude drone flights (e.g., [35]). 


\subsection{Macroplastic Transport}

Transport of macroplastic begins when its particles start to be moved by river flow after their input to an active river zone, or when stored macroplastic is remobilized by floodwater or bank erosion. The occurrence and intensity of this phase depends primarily on fluvial processes (e.g., flood occurrence) which influence the movement of plastic debris in rivers determining the duration and frequency of exposure of the debris to flowing water and controlling the spatial extent of its transport $[12,27,53]$. The anthropogenic modification of river hydrodynamics (e.g., by hydropeaking) and of the potential for erosion of the storage zone (e.g., by reinforcement of riverbanks and floodplain disconnection by flood embankments) influences the transport of macroplastic. Bank reinforcement, groynes and flood embankments may disconnect a given part of the macroplastic storage zone from river processes and prevent the remobilization of macroplastic (Figure 1B), as was similarly found for heavy metal-polluted floodplain sediments (e.g., [54]). The flow hydrodynamics has been suggested to act as an important control on the distance and intensity of macroplastic transport [53]. The lack of natural or artificial obstructions to river flow will probably favor the transport of plastic debris in narrow, regulated channels with simplified morphology and lacking vegetated islands and in-channel vegetation, as has also been found for large wood pieces (cf. [44]). During the transport phase, plastic debris interacts mechanically with water and sediments transported by the river, which causes its particles to become mechanically fragmented [12,22]. Their size decreases and surface area increases, implying a higher potential for further transport as well as biochemical degradation (e.g., during the storage phase) (see [12]). The rate of mechanical degradation of macroplastic will depend on the type of plastic, number of transport and storage events, during which plastic items may interact mechanically with water and sediment load transported by river, and on characteristics of the river sediments themselves (e.g., grain size) [12]. It may be hypothesized that in high-energy mountain rivers, which transport coarse sediments, the rate of mechanical degradation of plastic will be higher than in low-energy rivers transporting fine sediments. The process of riverine macroplastic fragmentation is important because it is assumed to be a main source of microplastic in rivers (see [55]) (Figure 1A). Different densities and buoyancy capabilities of specific types of plastic debris determine the mode of its transport as bedload or suspended load [19].

To date, the transport of macroplastic debris has been quantified using detection of plastic particles from aerial photographs taken by a drone from low heights (5 and $15 \mathrm{~m}$; [35]). Macroplastic debris transport was also measured by visual counting from bridges, video approaches, trackers, net sampling, or from infrastructure or riverbanks (e.g., $[13,18,26,27,40,56])$. In future works, more details may be determined using a combination of a visual counting method with hydrodynamic modelling [57]. Insight into macroplastic transport distance may be also gained by modifications of the existing hydrodynamic models used for simulations of the transport of large woody debris (e.g., [44,58]), as well as by long-term observations of plastic accumulation on riverbanks [59].

\subsection{Macroplastic Storage}

A storage phase occurs after the natural or artificial placing of plastic debris in the storage zone or when plastic debris became deposited on the surface of river sediments or in vegetation (surface storage) or accumulated in river sediments below the river bed or floodplain surface (subsurface storage; Figure 1B). The zone of potential macroplastic storage can be assumed to be the areal extent of maximum floodplain inundation since the 1960s (Figure 1B), because only in this zone might plastic debris have been transported and deposited by river flow. Storage occurrence depends mainly on flood flows, which transport high amounts of macroplastic debris from upstream parts of a river catchment, and on local characteristics of the fluvial system, which control deposition. During a flood, macroplastic debris placed artificially or naturally on a floodplain surface may be transported downstream (e.g., $[23,27]$ ) or covered with mineral and organic sediments, and become stored without previous transport or remobilization (Figure 1A). The duration of macroplastic storage occurring near an active channel should be shorter than in distal parts of the river floodplain. High rates of 
the deposition of mineral and organic sediments in the storage zone would be a factor increasing the residence time of stored plastic. It can be hypothesized that a high sedimentation rate together with low flow energy at a given location would facilitate the covering of surface-stored macroplastic with mineral and organic sediments, and its transformation into subsurface storage, after which its remobilization potential would decrease. The density and buoyancy of specific types of plastic debris influence their transport mode [19]. Seasonal changes of riparian vegetation and modification of its floristic composition may increase surface roughness, favoring plastic storage during floods. From this perspective, the timing of floods in relation to the vegetation development phase may be an important temporal control on macroplastic storage. Anthropogenic or natural modifications of the type, density and structure of riparian vegetation change floodplain roughness (e.g., [60]), and thus they modify the potential for macroplastic storage. Anthropogenic modifications of floodplains (e.g., by dam or embankments construction) that occurred before and after the 1960s are crucial for the spatial pattern of macroplastic storage zone. For instance, flood embankments constructed after the 1960s confine an active storage zone and disconnect parts of the former storage zone, from which macroplastic cannot be remobilized during floods (Figure 1B). The storage zone can also be narrowed downstream from dams, where the channel typically incises and the floodplain zone is constricted laterally. Upstream from dams, the lateral extent of the storage zone should increase because of a wider extent of floodplain inundation during floods induced by reservoir backwater effect and bed aggradation [61].

The amount of stored macroplastic can be calculated using data on the volume of storage zone (based on known areal extent and mean thickness of sediments) and plastic abundance in the sediments. The thickness of the storage zone may be estimated using information on the presence of plastic debris in sediment cores taken from fluvial forms dated using aerial photographs, or in sediments visible in bank undercuts. Previous works on surface and subsurface storage of macroplastic debris used hand collection and sieve analysis for an estimation of plastic abundance (Table 1). Analysed samples were collected from quadrats [30,34,62,63], circles [64] or transects [65] delimited parallel or perpendicular to the shoreline of the river channel or reservoir [59]. Obtained results were usually described as number of plastic debris items or their mass per surface area $\left(\mathrm{m}^{2}\right)$ of sampled plot (Table 1), which is useful for estimation of plastic abundance in contemporary surface sediments, but does not allow for a reliable comparison with volumetric samples of sediments taken from cores or riverbanks. Importantly, this approach also does not allow for the calculation of the amount of macroplastic debris that can be remobilized from a given volume of eroded sediments. These problems can be resolved by collecting samples in a way that allows the mass of plastic in a given sediment volume to be established (see [66]). The volumetric approach was previously recommended for comparable sampling of microplastic $[14,67]$. Calculation of the abundance of macroplastic debris in sediment volume could also be useful in future studies utilizing samples taken from sediment cores or riverbanks. The volumetric method of sample collection may be implemented using existing approaches (e.g., [62,64]), making it possible to study the abundance of plastic debris in deposits of contemporary fluvial forms (e.g., channel bar, floodplain, island), and to compare this abundance with similar older deposits. Such an approach could also enable estimation of the total amount of plastic stored in a given river section or a whole river system, which is of crucial importance for a reliable estimation of the potential for its future remobilization by lateral migration of river channel. New insights into the storage phase may be also gained by adaption of certain field experiments developed by fluvial geomorphologists for studies of seed deposition (e.g., [68]) and approaches used up to now to determine the rate of macroplastic deposition on beaches (e.g., [34]) or in tidal marshes [30]. A recent remote sensing experiment suggests that storage of larger particles of macroplastic debris $(>2.5 \mathrm{~cm})$ can be effectively quantified from aerial photographs taken from low heights ( 5 to $40 \mathrm{~m}[35,37,39]$ ), which seems to be an effective alternative for hand collection of surface-deposited plastic debris in the areas with bare river sediments or hardly accessible areas of dam reservoir shorelines or deltas. 
During the storage phase, plastic particles are degraded by biochemical processes (Figure 1A). From a long-term perspective, a prolonged storage phase should decrease the amount of stored and remobilized macroplastic, but produce a certain quantity of microplastic which may be released to river waters or groundwater (Figure 1A).

\subsection{Macroplastic Remobilization}

Remobilization occurs when stored macroplastic debris is entrained by river flow or erosion processes (e.g., by bank erosion) and starts to be transported. Remobilization can encompass both surface and subsurface-stored macroplastic debris (Figure 1B). The remobilization of surface-stored macroplastic occurs when the debris is entrained by flow from the surface of riverbed, banks and floodplain or from riparian vegetation. Remobilization from subsurface storage can occur simultaneously, for instance, during bank erosion, when both surface- and subsurface-stored plastic particles are eroded (Figure 1B). The timescale of the transport and remobilization phases in a given part of fluvial system is controlled by the number and intensity of transport and remobilization events and complexity of a given system. These factors control both the potential for long-distance transport of macroplastic debris (e.g., [51]) and the storage time. Tramoy et al. [21] suggest that within biophysically complex systems and river sections with high storage potential (e.g., river estuary), a remobilization-storage cycle may last for centuries. New information on these processes may be gained from numerical simulations of a transport-storage-remobilization loop for longer time spans, and with different scenarios of new plastic inputs.

The extent of a remobilization zone can be mapped in future works as the area of the storage zone influenced by fluvial processes in a given period. The areal extent of the remobilization zone may be calculated using information on bank erosion or channel migration rates in a given river reach. Such analysis may be done using GIS techniques and remote sensing data (e.g., aerial photographs) commonly used in fluvial geomorphology to study channel changes. The amount of remobilized macroplastic may be estimated using data on the abundance of surface- and subsurface-stored macroplastic, and either the area of inundated floodplain or the volume of eroded floodplain sediments. Remobilization can be expressed as the amount of macroplastic (e.g., $\mathrm{kg}$ or items number) remobilized from the unit of storage zone (e.g., km of river length, $\mathrm{km}^{2}$ of the area of storage zone, $\mathrm{m}^{3}$ of the volume of storage zone) per time. Similar to macroplastic transport, future insights into macroplastic remobilization can be gained by simulations with use of existing hydrodynamic models e.g., [44]. However, such works will need further studies of the flow parameters needed to entrain particles of plastic debris deposited on given sediments or anchored on given vegetation types cf. [30].

\subsection{Macroplastic Output}

The output phase is defined as natural transport of macroplastic debris out of a fluvial system (e.g., from river to the ocean or estuary) or its given part (e.g., subcatchment, section or reach of river), or its artificial removal by cleanup actions or infrastructure (Figure 1). This phase is controlled by both natural (e.g., the number and intensity of transport and remobilization events, complexity of a given river system (e.g., [21]), wind) and artificial factors (e.g., cleanup activities [15,64]). Similar to the transport phase, a lower complexity of river systems may favor the occurrence of macroplastic output because of a lower possibility of the occurrence of multiple cycles of transport-storage-remobilization (cf. [21]). It can be also hypothesized that for channelized and embanked rivers (with constricted channel and floodplain zones, increased channel slope and high floodwater energy), the output potential will be higher than for naturally complex rivers with wider channel and floodplain zones and more diverse morphology and riparian vegetation, which favor the storage of macroplastic and prevent its downstream transport. In turn, river estuaries have been identified as possible temporary sinks for macroplastic that may delay its input from rivers to the ocean [21,69]. Similar to the transport phase, the output phase may also be temporarily modified by hydropeaking or sediment flushing events occurring downstream from dams. The intensity of an output phase may be measured in the same 
way as for the transport phase (e.g., [27,40,56]). Finally, it can be also hypothesized that a proportion of surface-stored macroplastic debris may be transported by wind outside the storage/remobilization zone, hence being removed from the area potentially influenced by fluvial processes (Table 1).

Table 1. Methods used in selected case studies for quantification of the abundance of macroplastic debris in different sediment types.

\begin{tabular}{|c|c|c|}
\hline Reference & Habitat Type, Sampling Description & Results Unit \\
\hline$[69]$ & $\begin{array}{l}\text { Lake shoreline. Surface sediments. Hand collection of all artificial litter (including } \\
\text { plastic) along variable-width zone of } 7.8 \mathrm{~km}(2 \% \text { of lake shoreline). }\end{array}$ & $\begin{array}{l}\mathrm{g} / \mathrm{km} \\
\% \text { of items type }\end{array}$ \\
\hline$[63]$ & $\begin{array}{l}\text { Reservoir shoreline survey ( } 2 \text { replicates, } 2 \text { seasons), hand collection of macroplastic } \\
\text { debris }(>2.5 \mathrm{~cm} \text { ) within } 5 \times 5 \text { m quadrats located from } 0 \text { to } 50 \mathrm{~m} \text { from shoreline. }\end{array}$ & $\begin{array}{l}\text { items/site } \\
\mathrm{g} / \mathrm{site}\end{array}$ \\
\hline [65] & $\begin{array}{l}\text { Riverbank and channel zone. Surface sediment: hand collection of all } \\
\text { anthropogenic litter (including plastic) along riverbank within 10-m-wide zone of } \\
\text { water edge and in river channel along three } 70-100 \mathrm{~m} \text { reaches. Lake beaches. } \\
\text { Surface sediments: hand collection along three } 400 \times 50 \mathrm{~m} \text { transects of shoreline } \\
\text { (3-day surveys). }\end{array}$ & $\begin{array}{l}\text { items } / \mathrm{m}^{2} \\
\mathrm{~g} / \mathrm{m}^{2} \\
\text { surface area }\left(\mathrm{cm}^{2}\right) / \mathrm{m}^{2}\end{array}$ \\
\hline [48] & $\begin{array}{l}\text { Riverbanks and floodplain sampled monthly (during the years 2014-2017) along } \\
\text { whole river course from source to estuary. Surface sediments: hand collection of all } \\
\text { artificial litter (including plastic) ( }>5 \mathrm{~mm} \text { ) within sites selected along whole } \\
\text { fluvial system. }\end{array}$ & $\begin{array}{l}\text { items/site } \\
\mathrm{kg} / \mathrm{site} \\
\text { types }(\%) \text { of items/site } \\
\text { items/collection } / 100 \mathrm{~m}\end{array}$ \\
\hline [62] & $\begin{array}{l}\text { Riverbank. Surface and subsurface sediments. Hand collection of macroplastic } \\
(>2.5 \mathrm{~cm}) \text { within two, randomly chosen transects }(3 \times 50 \mathrm{~m}) \text { selected parallel to the } \\
\text { riverbank and covering more than } 20 \% \text { of shoreline section. Mesoplastic } \\
(0.5-2.5 \mathrm{~cm}) \text { collection by sieving (using stainless sieves of } 5 \mathrm{~mm} \text { mesh size) of the } \\
\text { top } 3 \mathrm{~cm} \text { layer of sediments within three } 1 \mathrm{~m}^{2} \text { quadrats, randomly located in each } \\
\text { macroplastic transect, following the macroplastic collection. }\end{array}$ & $\begin{array}{l}\text { items } / \text { transect } \\
\text { items } / \mathrm{m}^{2}\end{array}$ \\
\hline [35] & $\begin{array}{l}\text { River channel and bank. Flowing water and surface sediments. Identification of } \\
\text { macroplastic }(>2 \mathrm{~cm}) \text { from aerial photographs done using UAV (DJI Phantom } 4 \text { ) } \\
\text { from the altitude of } 5 \text { and } 15 \mathrm{~m} \text {. }\end{array}$ & items $/ \mathrm{m}^{2}$ \\
\hline [64] & $\begin{array}{l}\text { Riverbank and floodplain. Surface sediments: hand collection of all artificial litter } \\
\left.\text { (including plastic) within three sampling sites (circle of radius } 1.5 \mathrm{~m}, \sim 7 \mathrm{~m}^{2}\right) \text { located } \\
\text { within river edge }(0-5 \mathrm{~m} \text { from channel), riverbank }(5-15 \mathrm{~m}) \text { and river crest }(>15 \mathrm{~m}) \\
\text { along the transect perpendicular to river course (up to three transects per site) }\end{array}$ & $\begin{array}{l}\text { items } / \mathrm{m}^{2} \\
\text { surface area of items } \\
\left(\%, \mathrm{~m}^{2}\right) / \mathrm{m}^{2} \text { or } / \text { site }\end{array}$ \\
\hline [66] & $\begin{array}{l}\text { Riverbank. Surface and subsurface sediments. Hand collection (steel spoon) of } \\
2-3 \mathrm{~kg} \text { samples within the area of } 15-20 \mathrm{~cm}^{2} \text {, followed by sieve analysis (mesh } \\
\text { sizes: } 10 \mathrm{~mm}, 5 \mathrm{~mm}, 850 \mu \mathrm{m}, 63 \mu \mathrm{m} \text { ) and density separation in } \mathrm{ZnCl}_{2} \text { solution. }\end{array}$ & $\begin{array}{l}\mathrm{ng} / \mathrm{g} \text { (mass fraction) } \\
\text { items/kg }\end{array}$ \\
\hline [70] & $\begin{array}{l}\text { Riverbank (river marsh), surface sediments: hand collection of macro }(>2.5 \mathrm{~cm}) \\
\text { and mesoplastic debris }(0.5-2.5 \mathrm{~cm}) \text {. }\end{array}$ & $\begin{array}{l}\text { items } / \mathrm{m}^{2} \\
\mathrm{~g} / \mathrm{m}^{2} \\
\mathrm{~g} / \text { item type } \\
\% \text { of items } \\
\text { type/total items }\end{array}$ \\
\hline [30] & $\begin{array}{l}\text { Tidal zone, habitats of different vegetation types. Emergent and underwater } \\
\text { surface sediments: hand collection of macroplastic debris }(>0.5 \mathrm{~cm} \text { ) within three } 5 \\
\times 5 \mathrm{~m} \text { quadrats per plot (surface sediments in intertidal zone) and three } \\
\text { underwater band transects } 6 \times 4 \mathrm{~m} \text { (subtidal zone). Macroplastic debris size } \\
\text { classified at } 10 \text {-cm intervals. }\end{array}$ & $\begin{array}{l}\text { items } / 100 \mathrm{~m}^{2} \\
\mathrm{~kg} / 100 \mathrm{~m}^{2} \\
\% \text { of items/habitat type }\end{array}$ \\
\hline [21] & $\begin{array}{l}\text { River estuary (old dredging chamber, active floodplain, floodplain part } \\
\text { disconnected by artificial levee). Surface sediments: targeted collection of microlax } \\
\text { packaging items with printed use-by dates. }\end{array}$ & $\begin{array}{l}\text { types and number of } \\
\text { plastic debris with } \\
\text { date-prints items } \\
(\text { microlax)/site }\end{array}$ \\
\hline [34] & $\begin{array}{l}\text { Marine beach, surface sediments: hand and sieve collection of macroplastic debris } \\
(>2 \mathrm{~mm} \text { and }>5 \mathrm{~mm}) \text { within five } 5 \times 30 \mathrm{~m} \text { and ten } 20 \times 2 \mathrm{~m} \text { transects. Subsurface } \\
\text { sediments }(0-10 \mathrm{~cm}) \text { : sieve collection of macroplastic debris in ten } 0.4 \times 0.4 \mathrm{~m} \\
\text { quadrats. Monitoring of plastic debris accumulation along } 10 \times 0.2 \mathrm{~m} \text { transect (six } \\
\text { days). Total amount of debris calculated as mean surface/subsurface densities per } \\
\text { site area. }\end{array}$ & $\begin{array}{l}\text { items } / \mathrm{m}^{2} \\
\mathrm{~kg} / \mathrm{site}\end{array}$ \\
\hline [71] & $\begin{array}{l}\text { Marine beach. Surface and subsurface sediments. Hand collection and sieving of } \\
\text { top } 5 \mathrm{~cm} \text { layer of sediments within } 18 \text { quadrats } 1 \mathrm{~m}^{2} \text { in size located at equal } \\
\text { distances of } 5 \mathrm{~m} \text { along three transects parallel to beach (repeated twice at the } \\
\text { same location). }\end{array}$ & $\begin{array}{l}\text { items } / \mathrm{m}^{2} \\
\text { maximum linear length } \\
\text { of plastic litter }\end{array}$ \\
\hline
\end{tabular}




\section{Perspectives on Future Work}

Research on macroplastic in the river environment is an emerging branch of river science, and its methodological and theoretical background is developing now. In this paper we aimed to shed light on the processes of riverine macroplastic storage and remobilization, which have been overlooked to date in the literature. Our conceptual model provides a framework that defines phases of the macroplastic route through a fluvial system and systematizes their main controls. The proposed model is based on the assumption that the fate of macroplastic in a fluvial system is controlled by natural and anthropogenic factors, the importance of which changes between different phases of its route through the system (Figures 1 and 2). The key factors controlling macroplastic storage and remobilization are related to natural characteristics of fluvial systems (especially river flow and valley morphology), and their anthropogenic modifications. The type and number of these controls change along different spatial units of a fluvial system, and the control factors operating at larger units (e.g., catchment) additionally influence the control factors active at smaller units (e.g., reach) (Figure 2). The proposed model presents a general qualitative scheme, which may be quantitatively developed in future works based on a greater number of case studies. The temporal coincidence of the beginning of plastic debris accumulation in the environment in the 1960s [1] and of widespread availability of historical remote sensing materials (e.g., aerial photographs) and hydrological data gives a unique opportunity to map macroplastic storage and remobilization zones since the beginning of the plastic era. Information about the abundance of plastic in contemporary and older sediments of the storage zone should be expressed in the same metrics, which would allow for an easier comparison of the abundance of plastic debris between fluvial forms and sedimentary facies of different age and for precise assessment of the total amount of plastic stored in the river environment. Our proposed framework will contribute to a better quantification and understanding of macroplastic accumulation and transport mechanisms in river systems. Future studies may expand on our work by assessing the environmental impact more realistically. Current methods commonly used to quantify the environmental impact of plastic products, such as life cycle assessments, can be improved by more accurate estimates of the fate, fragmentation rates, and retention of plastics in specific components of river systems (e.g., sediments, on river bed, in riparian vegetation).

A demonstrated diversity of factors controlling the route of macroplastic through a fluvial system requires a broader, transdisciplinary perspective that would include among functional components humans, who not only dispose plastic, but are also affected by it both physically and aesthetically, and who may remove it from rivers.

Author Contributions: M.L. formulated a concept of the paper, wrote its original draft and developed the model of macroplastic route through a fluvial system, J.L. reviewed relevant literature and discussed model implications, P.M. prepared illustrations to the text, and T.v.E. and B.W. improved the original text and figures. All authors have read and agreed to the published version of the manuscript.

Funding: This research received no external funding.

Acknowledgments: We thank two anonymous reviewers for their critical comments on the manuscript.

Conflicts of Interest: The authors declare no conflict of interest.

\section{References}

1. Zalasiewicz, J.; Waters, C.N.; Sul, J.I.D.; Corcoran, P.L.; Yonan, Y. The geological cycle of plastics and their use as a stratigraphic indicator of the Anthropocene. Anthropocene 2016, 13, 4-17. [CrossRef]

2. Barnes, D.K.A.; Galgani, F.; Thompson, R.C.; Barlaz, M. Accumulation and fragmentation of plastic debris in global environments. Philos. Trans. R. Soc. B 2019, 364, 1985-1998. [CrossRef]

3. Thompson, R.C.; Swan, S.H.; Moore, C.J.; vom Saal, F.S. Our plastic age. Philos. Trans. R. Soc. B 2009, 364, 1973-1976. [CrossRef] 
4. Zalasiewicz, J.; Gabbott, S.; Waters, C.N. Plastic waste: How plastics have become part of the Earth's geological cycle. In Waste: A Handbook for Management; Letcher, T.M., Vallero, D.A., Eds.; Academic Press: London, UK, 2019; pp. 443-451. [CrossRef]

5. Thompson, R.C.; Olsen, Y.; Mitchell, R.P.; Davis, A.; Rowland, S.J.; John, A.W.G.; McGonigle, G.; Russell, A.E. Lost at sea: Where is all the plastic? Science 2004, 304, 838. [CrossRef] [PubMed]

6. Thompson, R.C.; Moore, C.J.; vom Saal, F.S.; Swan, S.H. Plastics, the environment and human health: Current consensus and future trends. Philos. Trans. R. Soc. B 2009, 364, 2153-2166. [CrossRef] [PubMed]

7. Koelmans, A.A.; Besseling, E.; Foekema, E.; Kooi, M.; Mintenig, S.; Ossendorp, B.C.; Redondo-Hasselerharm, P.E.; Verschoor, A.; van Wezel, A.P.; Scheffer, M.; et al. Risks of plastic debris: Unravelling fact, opinion, perception, and belief. Environ. Sci. Technol. 2017, 51, 11513-11519. [CrossRef]

8. Chae, Y.; An, Y.-J. Current research trends on plastic pollution and ecological impacts on the soil ecosystem: A review. Environ. Pollut. 2018, 240, 387-395. [CrossRef] [PubMed]

9. Rist, S.; Almroth, B.C.; Hartmann, N.B.; Karlsson, T.M. A critical perspective on early communications concerning human health aspects of microplastics. Sci. Total Environ. 2018, 626, 720-726. [CrossRef]

10. Bank, M.S.; Hansson, S.V. The plastic cycle: A novel and holistic paradigm for the Anthropocene. Environ. Sci. Technol. 2019, 53, 7177-7179. [CrossRef] [PubMed]

11. Blettler, M.C.; Wantzen, K.M. Threats underestimated in freshwater plastic pollution: Mini-review. Water Air Soil Pollut. 2019, 230, 174. [CrossRef]

12. Hurley, R.; Horton, A.; Lusher, A.; Nizzetto, L. Plastic waste in the terrestrial environment. Plast. Waste Recycl. 2020, 163-193. [CrossRef]

13. van Emmerik, T.; Schwarz, A. Plastic debris in rivers. WIREs. Water 2020, 7, 1-24. [CrossRef]

14. Waldschläger, K.; Lechthaler, S.; Stauch, G.; Schüttrumpf, H. The way of microplastic through the environment-Application of the source-pathway-receptor model (review). Sci. Total Environ. 2020, 713, 136584. [CrossRef] [PubMed]

15. Winton, D.J.; Anderson, L.G.; Rocliffe, S.; Loiselle, S. Macroplastic pollution in freshwater environments: Focusing public and policy action. Sci. Total Environ. 2020, 704, 135242. [CrossRef] [PubMed]

16. Blettler, M.C.; Abrial, E.; Khan, F.R.; Sivri, N.; Espinola, L.A. Freshwater plastic pollution: Recognizing research biases and identifying knowledge gaps. Water Res. 2018, 143, 416-424. [CrossRef] [PubMed]

17. Schmidt, C.; Krauth, T.; Wagner, S. Export of plastic debris by rivers into the sea. Environ. Sci. Technol. 2017, 51, 12246-12253. [CrossRef]

18. van Calcar, C.J.; van Emmerik, T. Abundance of plastic debris across European and Asian rivers. Environ. Res. Lett. 2019, 14, 124051. [CrossRef]

19. Gabbott, S.; Russell, C.; Yohan, Y.; Zalasiewicz, J. The geography and geology of plastics: Their environmental distribution and fate. Plast. Waste Recycl. 2020, 33-63. [CrossRef]

20. He, B.; Goonetilleke, A.; Ayoko, G.A.; Rintoul, L. Abundance, distribution patterns, and identification of microplastics in Brisbane River sediments, Australia. Sci. Total Environ. 2020, 700, 134467. [CrossRef]

21. Tramoy, R.; Gasperi, J.; Colasse, L.; Tassin, B. Transfer dynamic of macroplastics in estuaries-New insights from the Seine estuary: Part 1. Long term dynamic based on date-prints on stranded debris. Mar. Pollut. Bull. 2020, 152, 110894. [CrossRef]

22. Horton, A.A.; Dixon, S.J. Microplastic: An introduction to environmental transport processes. WIREs. Water 2017, 5, e1268. [CrossRef]

23. Hurley, R.; Woodward, J.; Rothwell, J.J. Microplastic contamination of river beds significantly reduced by catchment-wide flooding. Nat. Geosci. 2018, 11, 251-257. [CrossRef]

24. Wagner, S.; Klockner, P.; Stier, B.; Romer, M.; Seiwert, B.; Reemtsma, T.; Schmidt, C. Relationship between discharge and river plastic concentrations in a rural and an urban catchment. Environ. Sci. Technol. 2019, 53, 10082-10091. [CrossRef] [PubMed]

25. Windsor, F.M.; Durance, I.; Horton, A.A.; Thompson, R.C.; Tyler, C.R.; Ormerod, S.J. A catchment-scale perspective of plastic pollution. Glob. Chang. Biol. 2019, 25, 1207-1221. [CrossRef]

26. van Emmerik, T.; Strady, E.; Kieu-Le, T.; Nguyen, L.; Gratiot, N. Seasonality of riverine macroplastic transport. Sci. Rep. 2019, 9, 1-9. [CrossRef] 
27. van Emmerik, T.; Tramoy, R.; van Calcar, C.; Alligant, S.; Treilles, R.; Tassin, B.; Gasperi, J. Seine plastic debris transport tenfolded during increased river discharge. Front. Mar. Sci. 2019, 6, 642. [CrossRef]

28. Guerranti, C.; Perra, G.; Martellini, T.; Giari, L.; Cincinelli, A. Knowledge about microplastic in Mediterranean tributary river ecosystems: Lack of data and research needs on such a crucial marine pollution source. J. Mar. Sci. Eng. 2020, 8, 216. [CrossRef]

29. Nihei, Y.; Yoshida, T.; Kataoka, T.; Ogata, R. High-resolution mapping of Japanese microplastic and macroplastic emissions from the land into the sea. Water 2020, 12, 951. [CrossRef]

30. Cozzolino, L.; Nicastro, K.R.; Zardi, G.I.; de los Santos, C.B. Species-specific plastic accumulation in the sediment and canopy of coastal vegetated habitats. Sci. Total Environ. 2020, 723, 138018. [CrossRef]

31. Bonney, R.; Shirk, J.L.; Phillips, T.B.; Wiggins, A.; Ballard, H.L.; Miller-Rushing, A.J.; Parrish, J.K. Next steps for citizen science. Science 2014, 243, 1427-1436. [CrossRef]

32. Heidbreder, M.; Bablok, I.; Drews, S.; Menzel, C. Tackling the plastic problem: A review on perceptions, behaviours, and interventions. Sci. Total Environ. 2019, 668, 1077-1093. [CrossRef] [PubMed]

33. Henderson, L.; Green, C. Making sense of microplastics? Public understandings of plastic pollution. Mar. Pollut. Bull. 2020, 152, 110908. [CrossRef] [PubMed]

34. Lavers, J.L.; Bond, A.L. Exceptional and rapid accumulation of anthropogenic debris on one of the world's most remote and pristine islands. Proc. Natl. Acad. Sci. USA 2017, 114, 6052-6055. [CrossRef] [PubMed]

35. Geraeds, M.; van Emmerik, T.; de Vries, R.; bin Ab Razak, M.S. Riverine plastic litter monitoring using unmanned aerial vehicles (UAVs). Remote Sens. 2019, 11, 2045. [CrossRef]

36. Martínez-Vicente, V.; Clark, J.R.; Corradi, P.; Aliani, S.; Arias, M.; Bochow, M.; Bonnery, G.; Cole, M.; Cózar, A.; Donnelly, R.; et al. Measuring marine plastic debris from space: Initial assessment of observation requirements. Remote Sens. 2019, 11, 2443. [CrossRef]

37. Andriolo, U.; Gonçalves, G.; Bessa, F.; Sobral, P. Mapping marine litter on coastal dunes with unmanned aerial systems: A showcase on the Atlantic Coast. Sci. Total Environ. 2020, 736, 139632. [CrossRef]

38. Biermann, L.; Clewley, D.; Martinez-Vicente, V.; Topouzelis, K. Finding plastic patches in coastal waters using optical satellite data. Sci. Rep. 2020, 10,1-10. [CrossRef]

39. Gonçalves, G.; Andriolo, U.; Pinto, L.; Duarte, D. Mapping marine litter with unmanned aerial systems: A showcase comparison among manual image screening and machine learning techniques. Mar. Pollut. Bull. 2020, 155, 111158. [CrossRef]

40. Kataoka, T.; Nihei, Y. Quantification of floating riverine macro-debris transport using an image processing approach. Sci. Rep. 2020, 10,1-11. [CrossRef]

41. Merlino, S.; Paterni, M.; Berton, A.; Massetti, L. Unmanned aerial vehicles for debris survey in coastal areas: Long-term monitoring programme to study spatial and temporal accumulation of the dynamics of beached marine litter. Remote Sens. 2020, 12, 1260. [CrossRef]

42. Leopold, L.B.; Wolman, M.G.; Miller, J.P. Fluvial Processes in Geomorphology; Freeman: San Francisco, CA, USA, 1964; p. 522. ISBN 978-0486685885.

43. Gurnell, A.M.; Piégay, H.; Swanson, F.J.; Gregory, S.V. Large wood and fluvial processes. Freshw. Biol. 2002, 47, 601-619. [CrossRef]

44. Ruiz-Villanueva, V.; Piégay, H.; Gurnell, A.M.; Marston, R.A.; Stoffel, M. Recent advances quantifying the large wood dynamics in river basins: New methods and remaining challenges. Rev. Geophys. 2016, 54, 611-652. [CrossRef]

45. Shumilova, O.; Tockner, K.; Gurnell, A.M.; Langhans, S.D.; Righetti, M.; Lucía, A.; Zarfl, C. Floating matter: A neglected component of the ecological integrity of rivers. Aquat. Sci. 2019, 81, 25. [CrossRef]

46. Hoellein, T.J.; Shogren, A.J.; Tank, J.L.; Risteca, P.; Kelly, J.J. Microplastic deposition velocity in streams follows patterns for naturally occurring allochthonous particles. Sci. Rep. 2019, 9, 1-11. [CrossRef]

47. Ockelford, A.; Cundy, A.; Ebdon, J.E. Storm response of fluvial sedimentary microplastics. Sci. Rep. 2020, 10, 1-10. [CrossRef]

48. Bruge, A.; Barreau, C.; Carlot, J.; Collin, H.; Moreno, C.; Maison, P. Monitoring litter inputs from the Adour River (Southwest France) to the marine environment. J. Mar. Sci. Eng. 2018, 6, 24. [CrossRef]

49. Wohl, E.; Kramer, N.; Ruiz-Villanueva, V.; Scott, D.N.; Comiti, F.; Gurnell, A.M.; Piégay, H.; Lininger, K.B.; Jaeger, K.L.; Walters, D.M.; et al. The natural wood regime in rivers. BioScience 2019, 69, 259-273. [CrossRef] 
50. Tramoy, R.; Gasperi, J.; Dris, R.; Colasse, L.; Fisson, C.; Sananes, S.; Rocher, V.; Tassin, B. Assessment of the plastic inputs from the Seine basin to the sea using statistical and field approaches. Front. Mar. Sci. 2019, 6, 151. [CrossRef]

51. Weideman, E.A.; Perold, V.; Ryan, P.G. Limited long-distance transport of plastic pollution by the Orange-Vaal River system, South Africa. Sci. Total Environ. 2020, 727, 138653. [CrossRef]

52. Malinowski, M.; Wolny-Koładka, K.; Jastrzębski, B. Characteristics of illegal dumping sites—Case study: Watercourses. Infrastrukt. Ekol. Teren. Wiej. 2015, 4, 1475-1484. [CrossRef]

53. Castro-Jiménez, J.; González-Fernández, D.; Fornier, M.; Schmidt, N.; Sempere, R. Macro-litter in surface waters from the Rhone River: Plastic pollution and loading to the NW Mediterranean Sea. Mar. Pollut. Bull. 2019, 146, 60-66. [CrossRef]

54. Ciszewski, D.; Grygar, T.M. A Review of flood-related storage and remobilization of heavy metal pollutants in river systems. Water Air Soil Pollut. 2016, 227, 239. [CrossRef] [PubMed]

55. van Wijnen, J.A.; Ragas, M.J.; Kroeze, C. Modelling global river export of microplastics to the marine environment: Sources and future trends. Sci. Total Environ. 2019, 673, 392-401. [CrossRef] [PubMed]

56. van Emmerik, T.; Kieu-Le, T.-C.; Loozen, M.; van Oeveren, K.; Strady, E.; Bui, X.-T.; Egger, M.; Gasperi, J.; Lebreton, L.; Nguyen, P.-D.; et al. A methodology to characterize riverine macroplastic emission into the ocean. Front. Mar. Sci. 2018, 5, 372. [CrossRef]

57. van Emmerik, T.; Loozen, M.; Van Oeveren, K.; Buschman, F.; Prinsen, G. Riverine plastic emission from Jakarta into the ocean. Environ. Res. Lett. 2019, 14, 08403. [CrossRef]

58. Wyżga, B.; Mikuś, P.; Zawiejska, J.; Ruiz-Villanueva, V.; Kaczka, R.J.; Czech, W. Log transport and deposition in incised, channelized, and multithread reaches of a wide mountain river: Tracking experiment during a 20-year flood. Geomorphology 2017, 279, 98-111. [CrossRef]

59. Vriend, P.; van Emmerik, T.; Roebroek, C.T.J. Same but different: A framework to design and compare riverbank plastic monitoring strategies. Earth Ar Xiv 2020. [CrossRef]

60. Kiss, T.; Nagy, J.; Fehérváry, I.; Vaszkó, C. (Mis) management of floodplain vegetation: The effect of invasive species on vegetation roughness and flood levels. Sci. Total Environ. 2019, 686, 931-945. [CrossRef]

61. Liro, M. Dam reservoir backwater as a field-scale laboratory of human-induced changes in river biogeomorphology: A review focused on gravel-bed rivers. Sci. Total Environ. 2019, 651, 2899-2912. [CrossRef]

62. Blettler, M.C.; Garello, N.; Ginon, L.; Abrial, E.; Espinola, L.A.; Wantzen, K.M. Massive plastic pollution in a mega-river of developing country: Sediment deposition and ingestion by fish (Prochilodus lineatus). Environ. Poll. 2019, 225, 113348. [CrossRef]

63. Dalu, T.; Malesa, B.; Cuthbert, R.N. Assessing factors driving the distribution and characteristics of shoreline macroplastics in a subtropical reservoir. Sci. Total Environ. 2019, 696, 133992. [CrossRef] [PubMed]

64. Kiessling, T.; Knickmeier, K.; Kruse, K.; Brennecke, D.; Nauendorf, A.; Thiel, M. Plastic Pirates sample litter at rivers in Germany-Riverside litter and litter sources estimated by schoolchildren. Environ. Pollut. 2019, 245, 545-557. [CrossRef]

65. Hoellein, T.J.; Rojas, M.; Pink, A.; Gasior, J.; Kelly, J. Anthropogenic litter in urban freshwater ecosystems: Distribution and microbial interactions. PLoS ONE 2014, 9, e98485. [CrossRef] [PubMed]

66. Sarkar, D.J.; Das Sarkar, S.; Das, B.K.; Manna, R.K.; Behera, B.J.; Srikanta, S. Spatial distribution of meso and microplastics in the sediments of river Ganga at eastern India. Sci. Total Environ. 2019, 694, 133712. [CrossRef] [PubMed]

67. Gurnell, A.; Thompson, K.; Goodson, J.; Moggridge, H. Propagule deposition along river margins: Linking hydrology and ecology. J. Ecol. 2008, 96, 553-565. [CrossRef]

68. Tramoy, R.; Colasse, L.; Gasperi, J.; Tassin, B. Plastic debris dataset on the Seine river banks: Plastic pellets, unidentified plastic fragments and plastic sticks are the Top 3 items in a historical accumulation of plastics. Data Brief 2019, 23, 103697. [CrossRef]

69. Acha, E.M.; Mianzan, H.W.; Iribarne, O.; Gagliardini, D.A.; Lasta, C.; Daleo, P. The role of the Rio de la Plata bottom salinity front in accumulating debris. Mar. Pollut. Bull. 2003, 46, 197-202. [CrossRef] 
70. Free, C.M.; Jensen, O.P.; Mason, S.A.; Eriksen, M.; Williamson, N.J. High-levels of microplastic pollution in a large, remote, mountain lake. Mar. Pollut. Bull. 2014, 85, 156-163. [CrossRef]

71. Ghaffari, S.; Bakhtiari, A.R.; Ghasempouri, S.M.; Nasrolahi, A. The influence of human activity and morphological characteristics of beaches on plastic debris distribution along the Caspian Sea as a closed water body. Environ. Sci. Pollut. Res. 2019, 26, 25712-25724. [CrossRef]

(C) 2020 by the authors. Licensee MDPI, Basel, Switzerland. This article is an open access article distributed under the terms and conditions of the Creative Commons Attribution (CC BY) license (http://creativecommons.org/licenses/by/4.0/). 